\title{
A Study of Sustainable Design Methods for Clothing Recycling from the Perspective of Reverse Thinking
}

\author{
Wenjun Guoa,b, Eunyoung Kimª \\ aJapan Advanced Institute of Science and Technology, Japan \\ 'Dalian Polytechnic University, China \\ *Corresponding author e-mail:s2020405@jaist.ac.jp,wenjun100@163.com
}

\begin{abstract}
:
Clothing disposal practice as the final stage of consumption plays an important role in the sustainable design of recycling. We extend this finding to the creation of sustainable design methods for clothing recycling by applying reverse thinking which focused on the concept of human-centred and sustainable driven design. A mixed method of combining qualitative and quantitative approaches was applied, and data was collected from three interviews and a survey. The results show that consumers are mainly driven by the products' intrinsic factors and psychological factors when disposing of clothes. There is a discrepancy between the requests of disposal organisations and the behaviour of consumers, as well as consumers' request for transparency in disposal channels. Thus, the methods for recycling from the dimensions of product, service and policy strategy were proposed by reflecting on the issues of clothing disposal of consumers.
\end{abstract}

[STYLE:_SH Abstract]

Keywords: sustainable design methods; clothing recycling; clothing disposal; reverse thinking

\section{Introduction}

Due to the issue of energy consumption by the textile and clothing industry and its environmental impact, sustainable design has become an inevitable trend in the field of fashion design (Claxton \& Kent, 2020; Diddi et al., 2019; Weber et al., 2017), and the demand for clothing disposal is thus increasing (Joung \& Park-Poaps, 2013). Many researchers are focussing their attention on sustainable fashion design and technology based on production dimension (Goworek et al., 2018; Kozlowski et al., 2018). There is also a focus on disposal practices and awareness based on the dimension of final stage of consumption (Young Lee et al., 2013; Kamis et al., 2019; Joung \& Park-Poaps, 2013). 
However, there are a limited number of studies on sustainable design methods following research on clothing disposal.

Reverse thinking, unlike positive thinking, advocates new points of view and new approaches to solving problems as well as promoting human-centred inclusive design (Myerson, 2016). In the context of the clothing industry, positive thinking is based on adopting the sequence of 'production consumption - disposal' (Goworek et al., 2018). The function of reverse thinking in this study is to address issues of production by reflecting on disposal with the concept of human-centred and sustainable driven design, both of which influence consumption and then to optimise disposal, as shown in Figure 1.

Positive Thinking: (market-oriented)

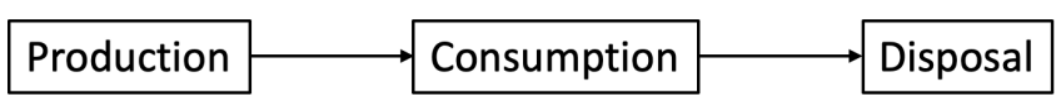

Reverse Thinking:
(human-centred and
sustainable driven
design)

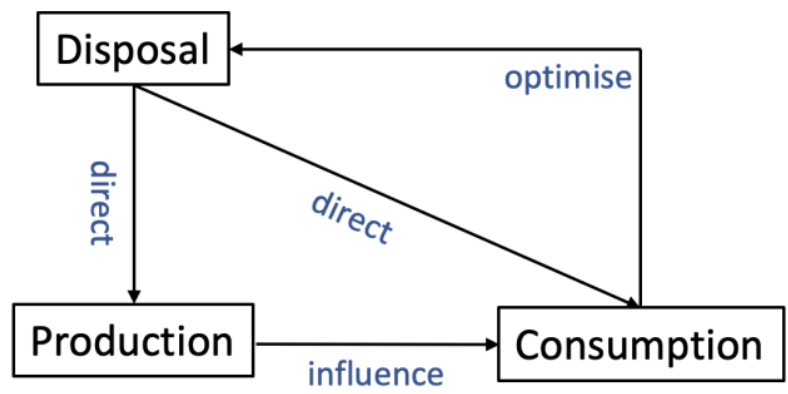

Figure 1. Comparison of positive thinking and diverse thinking in clothing life phases.

There are a number of issues which complicate the disposal of textile items. For instance, the use of polyester fibre which is refined from crude oil (D’Adamo \& Lupi, 2021), can harm the environment and be challenging to recycle. The use of blended fibres has made textiles difficult to sort and recycle (Hawley, 2009). For some low-priced and low-quality items (Joung \& Park-Poaps, 2013) recycling may not be economically viable as the costs of collecting and sorting exceed the value they would create (Morley et al., 2006). Meanwhile, the development of fast fashion 'with a short life cycle' (Joung \& Park-Poaps, 2013) and its strategies of encouraging consumers to buy in large quantities (Barnes et al., 2013) have also increased the pressure to dispose of clothing effectively.

This study sets out to develop a series of sustainable design methods for clothing recycling, by applying reverse thinking from the perspective of clothing disposal for designers, educators, students and relevant stakeholders. The specific research questions addressed in this study are

- How to create sustainable design methods for recycling by reflecting on the issues of disposal clothing?

- How can reverse thinking be applied to the creation of design methods for recycling?

\section{Literature Review}

\subsection{Clothing Disposal}

With the increase of clothing consumption, the demand for clothing disposal increases (Joung \& Park-Poaps, 2013). Clothing disposal practice is defined as the behaviour of getting rid of undesired 
clothes (Wai Yee et al., 2016). Consumers dispose of their unwanted clothes mainly because of the signs of wear and tear, poor fit, fashion issues and storage space (Laitala, 2014). Disposal as the final stage of the clothing consumption process (Shim, 1995) has a direct or indirect impact on the environment. Clothing disposal practices generally include: donation, giving away, resale, swapping, renting, recycling centre, recycling box in retail shop, using as raw material for other products, energy recovery and discarding (Joung \& Park-Poaps, 2013; Wai Yee et al., 2016; Weber et al., 2017; Ki et al., 2020; Degenstein et al., 2021) as shown in Figure 2. Inappropriate disposal practices of clothing products could have an even worse impact on the environment (Hu et al., 2014).

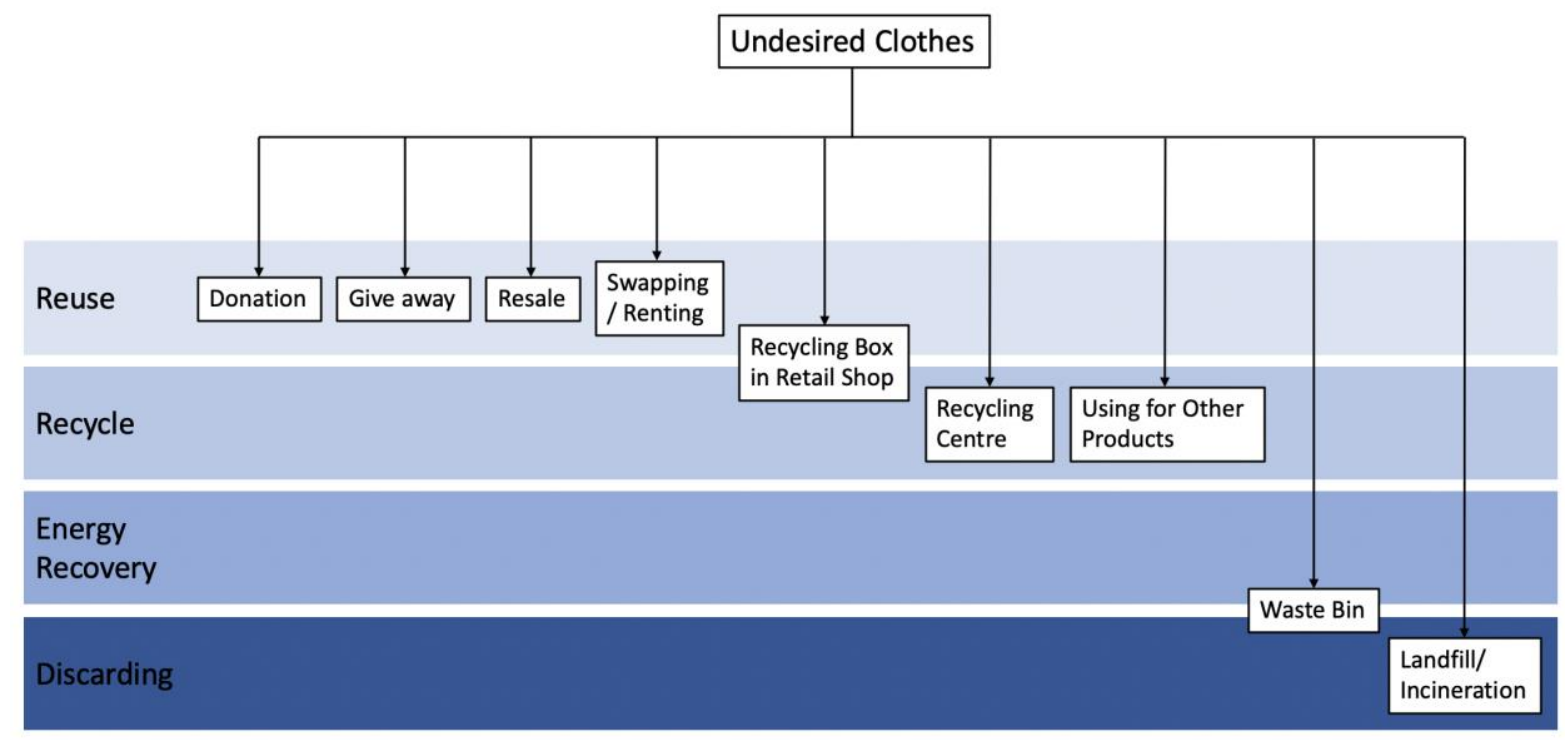

Figure 2. Disposal practices for undesired clothes (Bukhari et al., 2018; Degenstein et al., 2021)..

Textile waste consists of pre- and post-consumer textile materials (Joung \& Park-Poaps, 2013). Bukhari et al. (2018) conducted a case study on a French national recycling programme with the aim of illustrating the management of post-consumer textiles and clothing. The implementation of extended producer responsibility has promoted the development of recycling and proper textile disposal, which facilitates cooperation among different stakeholders and supports further development (Bukhari et al., 2018). Thus, sustainable design and recycling practices can be directed by the guidelines generated from the process of recycling and disposal (Karell \& Niinimäki, 2020; Bukhari et al., 2018).

\subsection{Reverse Thinking in the Design Method}

Reverse thinking is defined as alternative thinking that reverses the traditional way of thinking (Gao \& Huang, 2012). In contrast to positive thinking, reverse thinking helps to find solutions to issues from the potential negative directions of design and emphasises human-centred inclusive design (Myerson, 2016; Gao \& Huang, 2012).

Myerson (2016) explored the method of scaling down which highlighted the concept of humancentred design with reverse thinking compared with the trend of scaling up which aims to make large-scale production possible and apply to large groups of people to serve mass markets (p.288). The Boundary Estate project aimed at exploring the creation of the resident-centred lighting system using the approach of scaling down rather than making use of a generic urban lighting scheme. Thus, low-cost, low-energy fluorescent tubes were created according to the local situation (Myerson, 2016). 


\section{Method}

\subsection{Data Collection}

We collected qualitative data collection and analysis based on three semi-structured expert interviews of clothing disposal. Figure 3 shows the process of collecting the interview data, and Table 1 summarises the responses from the three interviews.

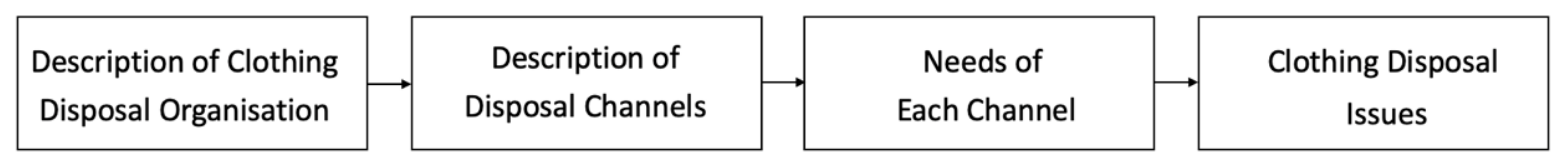

Figure 3. The process of collecting the interview data..

Table 1. Summary of the information of the three interviews.

\begin{tabular}{|c|c|c|}
\hline Affiliation & Position & Description of Clothing Disposal Channels \\
\hline \multirow[t]{4}{*}{$\begin{array}{l}\text { Online Clothing } \\
\text { Disposal } \\
\text { Platform A }\end{array}$} & $\begin{array}{l}\text { Business } \\
\text { Director }\end{array}$ & $\begin{array}{l}\text { The platform arranges a free door-to-door express } \\
\text { service to collect unwanted clothes after online } \\
\text { booking. }\end{array}$ \\
\hline & & $\begin{array}{l}\text { Channel 1: Regeneration of agricultural thermal } \\
\text { insulation materials, industrial sound insulation } \\
\text { materials and textiles - Some obstacles exist in the } \\
\text { development of the regeneration-oriented channel } \\
\text { due to the complexity of fabric composition and the } \\
\text { lack of related technology. }\end{array}$ \\
\hline & & $\begin{array}{l}\text { Channel 2: Donation - Aimed at Xinjiang, Tibet and } \\
\text { other regions of China, where almost new clothing, } \\
\text { especially winter clothing, is required. }\end{array}$ \\
\hline & & $\begin{array}{l}\text { Channel 3: Exported to Africa - High-quality, bright- } \\
\text { coloured summer clothing is required. }\end{array}$ \\
\hline \multirow[t]{5}{*}{$\begin{array}{l}\text { Online Clothing } \\
\text { Disposal } \\
\text { Platform B }\end{array}$} & Staff & $\begin{array}{l}\text { The platform arranges a free door-to-door express } \\
\text { service to collect unwanted clothes after online } \\
\text { booking, and users will be rewarded with phone } \\
\text { charges or gifts after successful disposal. }\end{array}$ \\
\hline & & $\begin{array}{l}\text { Channel 1: Regeneration of agricultural thermal } \\
\text { insulation materials, industrial sound insulation } \\
\text { materials, filling material and regenerated textiles. }\end{array}$ \\
\hline & & $\begin{array}{l}\text { Channel 2: Donation - Aimed at disadvantaged areas } \\
\text { of China. Suitable type, size and quantity of clothes } \\
\text { were selected according to the requirements of each } \\
\text { area. }\end{array}$ \\
\hline & & $\begin{array}{l}\text { Channel 3: Exported to Africa and some southeast } \\
\text { Asian countries - High-quality, summer clothing is } \\
\text { required. The income is used to maintain the } \\
\text { operation of the company. }\end{array}$ \\
\hline & & Channel 4: Transformation of clean energy. \\
\hline $\begin{array}{l}\text { Charity } \\
\text { Organisation }\end{array}$ & $\begin{array}{l}\text { Programme } \\
\text { Leader of }\end{array}$ & $\begin{array}{l}\text { Community textiles container setting with } \\
\text { government permission. }\end{array}$ \\
\hline
\end{tabular}




$\begin{array}{ll}\text { Clothing } & \text { Channel 1: Regeneration of industrial materials } \\ \text { Disposal } & \text { through crushing textiles. }\end{array}$

Channel 2: Donation: aimed at poor areas and poor households; high-durability clothing is required.

Based on the data collected from interviews, questionnaires for the survey were designed. A total of 139 people from different parts of China participated in the survey voluntarily, using online forms, between March 2021 and April 2021. The aim of this stage was to recognise consumers' clothing disposal practices and collect their requests for clothing disposal. The questionnaires contained: demographics, clothing disposal practices (including disposal reasons), disposal issues, and requests for disposal.

\subsection{Data Analysis Regarding the Utilisation of Reverse Thinking in Design Methods for Recycling}

Data analysis for the survey samples was based on both quantitative and qualitative approaches. First, respondents' demographics was analysed. Secondly, factor analysis was adopted for identifying the key factors affect disposal reasons and enabling the identification of some common features. Finally, the correlation coefficients calculation and test were adopted for disposal issues which include both quantitative responses and responses to an open-ended question.

Table 2 shows the demographics of survey respondents. A total of 139 respondents participated in the survey. The majority of the survey respondents (69.8\%) were female. The vast majority of women are responsible for clothes sorting according to the study.

Table 2. On the demographics of survey respondents..

\begin{tabular}{lll}
\hline & Number & Percentage (\%) \\
\hline Age & & \\
$\mathbf{1 6}-\mathbf{2 5}$ & 13 & 9.4 \\
$\mathbf{2 6}-\mathbf{3 5}$ & 38 & 27.3 \\
$\mathbf{3 6}-\mathbf{4 5}$ & 69 & 49.6 \\
$\mathbf{4 6}-\mathbf{5 5}$ & 11 & 7.9 \\
$\mathbf{5 6}-\mathbf{6 5}$ & 6 & 4.3 \\
$\mathbf{6 6}$ and above & 2 & 1.4 \\
\hline Gender & & \\
Male & 42 & 30.2 \\
Female & 97 & 69.8 \\
\hline
\end{tabular}

According to Jacoby's categories of factors that influence disposal choices (Jacoby et al., 1977), clothing disposal reasons were classified into five categories as shown in Table 3. Respondents could choose more than one option for this question. A total of 836 votes were collected. As shown in the table, the categories of 'psychological characteristics of the decision maker' and 'factors intrinsic to the product (natural factors)' were high-scoring choices with even distribution within the category, and the category of 'situational factors extrinsic to the product' shows an uneven distribution for each option.

Table 3. Categories of clothing disposal reasons.

Categories Clothing Disposal Reasons Count




\begin{tabular}{lll}
\hline $\begin{array}{l}\text { Factors intrinsic to } \\
\text { the product } \\
\text { (natural factors) }\end{array}$ & Wear and tear & 62 \\
\hline & Fading or mis-shaping due to long-term wear & 77 \\
Factors intrinsic to & Orims damaged or missing & 51 \\
the product & Pilling or fuzzing & 28 \\
(quality factors) & Burst at the seams or off-line & 42 \\
& Easily fades, cannot be washed with other clothes & 21 \\
\hline Factors intrinsic to & Stains cannot be removed & 12 \\
the product & Shrinking due to improper care & 48 \\
(maintenance & Mis-shaping due to improper care & 16 \\
factors) & Being dyed due to improper care & 21 \\
& Mouldy or moth-eaten & 29 \\
\hline $\begin{array}{l}\text { Psychological } \\
\text { characteristics of } \\
\text { the decision-maker }\end{array}$ & Out of fashion and no longer popular & 12 \\
\hline & Boredom & 77 \\
Situational factors & Poor fit & 67 \\
extrinsic to the & Response to the call of relevant activities of community & 6 \\
product & Requests of friends and relatives & 70 \\
\hline
\end{tabular}

Adequacy of the data was tested on the basis of results the Kaiser-Meyer-Olkin (KMO) measures of sampling adequacy and Bartlett's test of sphericity provided. The KMO measure of sampling adequacy is 0.781 , which indicates that the data is acceptable and suitable for factor analysis. Similarly, Bartlett's test of sphericity is significant $(p<0.001)$, which explains that all the extracted communalities are acceptable and variables are suitable for the factor solution as their extraction values are large enough. According to scree plot and total variance explained, the first five components have an Eigenvalues over 1 and the first two components have significance. Principal component analysis using component matrix was conducted to figure out the key factors of clothing disposal reasons (Table 4). It is shown that the loading for variables belong to factors intrinsic to the product (factors of natural, quality and maintenance are included) are higher than 0.3 on component 1. The loading for variables which belong to psychological characteristics of the decision-maker are higher than 0.4 on component 2 .

Table 4. Component Matrix.

\begin{tabular}{cccccc}
\hline \multicolumn{7}{c}{ Component } \\
\hline Wear and tear & 1 & 2 & 3 & 4 & 5 \\
\hline Fading & .529 & -.305 & -.391 & .093 & .190 \\
\hline Oldness & .332 & -.309 & .327 & .184 & .520 \\
\hline Trims damaged & .444 & -.414 & .321 & .169 & -.038 \\
\hline Pilling & .604 & -.163 & -.290 & .188 & -.010 \\
\hline Off-line & .710 & .100 & -.369 & .193 & -.004 \\
\hline Wash issues & .585 & .313 & -.331 & .078 & -.133 \\
\hline Stains & .683 & .183 & .132 & .208 & -.028 \\
\hline
\end{tabular}




\begin{tabular}{cccccc}
\hline Shrink & .701 & -.198 & .078 & -.230 & -.139 \\
\hline Mis-shaping & .660 & -.081 & .108 & -.287 & -.326 \\
\hline Being dyed & .721 & -.087 & -.123 & -.204 & -.187 \\
\hline Mouldy & .673 & .158 & .233 & -.240 & -.136 \\
\hline Outmoded & .294 & .476 & -.063 & -.353 & .392 \\
\hline Boredom & .193 & .499 & .427 & -.304 & .224 \\
\hline Matching issues & .174 & .603 & -.157 & -.060 & .051 \\
\hline Poor fit & .183 & .157 & .272 & .452 & -.152 \\
\hline Activities & .074 & .142 & .365 & .148 & -.531 \\
\hline Friends & .002 & .522 & .018 & .473 & -.113 \\
\hline Wardrobe & .271 & .248 & .052 & .340 & .306 \\
\hline
\end{tabular}

Table 5 shows the clothing disposal issues of respondents. Respondents could choose more than one option and a total of 465 votes were collected. The option of 'other' played the role of an openended option, allowing respondents to write their own answers, and total of 71 respondents chose this option. Issues were classified into four categories based on the meanings. The option 'unaware of the disposal channels', was most highly chosen, which indicates a lack of relevant knowledge and respondents' desire for disposal information.

Table 5. Disposal issues of respondents.

\begin{tabular}{lll}
\hline Categories & Clothing Disposal Issues & Count \\
\hline Lack of & V1: Unaware of the disposal channels & 59 \\
Knowledge & V2: Inconvenience of reaching the known disposal site & 35 \\
& V3: Payment of postage for independent donation & 13 \\
\hline Scepticism & V4: Distrust of disposal organisations & 35 \\
\hline Uncertainty & V5: Uncertainty about whether the old degree of clothes is suitable for & \\
& disposal & 34 \\
& V6: Uncertainty about whether the style is suitable for disposal & 17 \\
& V7: Uncertainty about whether the material is suitable for disposal & 12 \\
& V8: Uncertainty about whether it can be worn again & 51 \\
& V9: Uncertainty about whether it can be reused & 29 \\
\hline Ambivalence & V10: Unwilling to dispose due to emotional attachment & 47 \\
& V11: Unwilling to dispose due to the high purchase price & 42 \\
& V12: Worry that recipient would mind second-hand items or other factors & 20 \\
\hline & V13: Other & 71 \\
\hline
\end{tabular}

The collected data was analysed with correlation coefficients calculation through js-Star. Figure 4 shows that the linked variables are significantly correlated. Variable $8,10,11$ are strongly correlated with each other, which indicates that consumers' uncertainty about whether the clothes can be worn again are related to emotional attachment and the high purchase price. In other words, consumers would keep the clothes longer due to the emotional attachment and the high purchase price. Meanwhile, V6 and V7 are strongly correlated, which indicates that the consumers who are not sure about whether the style is suitable for disposal are not sure about whether the material is suitable for disposal either. It 
reflects that consumers are lack of the knowledge of clothing and disposal. In addition, V13, the openended option, is only correlated with $\mathrm{V} 4$, which presents the consumers' distrust attitude and the request of transparency of disposal channels.

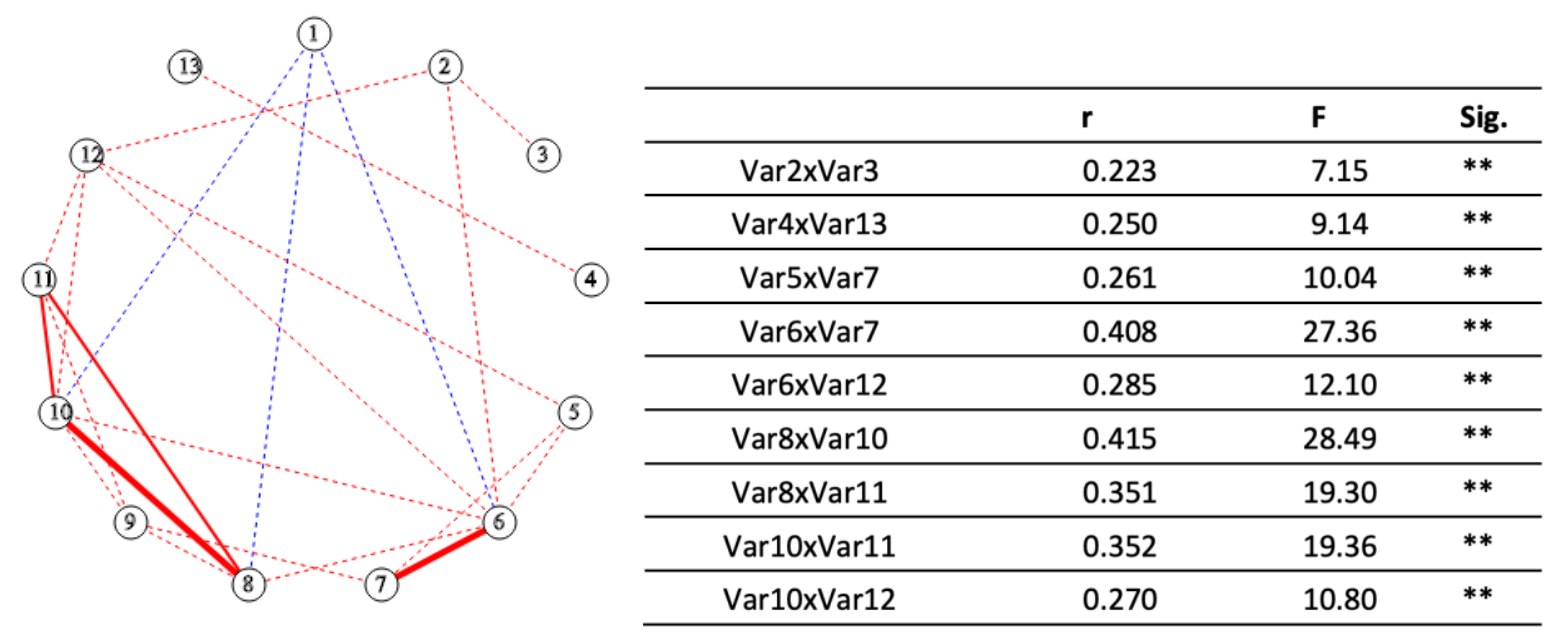

Figure 4. The correlation coefficients calculation and test of disposal issues.

\section{Results and Discussion}

By applying reverse thinking, the study aims to facilitate improving opportunities for recycling and emphasises the concept of human-centred and sustainable driven design, rather than the marketoriented design. The results of this study indicate that consumers are mainly driven by products' intrinsic factors and psychological factors for clothes disposal. There is a discrepancy between the requests of disposal organisations and the behaviour of consumers. In addition, the results suggest that consumers would appreciate greater transparency in disposal channels. The suggestion of design solution ideas for disposal reasons and issues, which involves the dimensions of product, service and policy strategy are summarised in Figure 5.

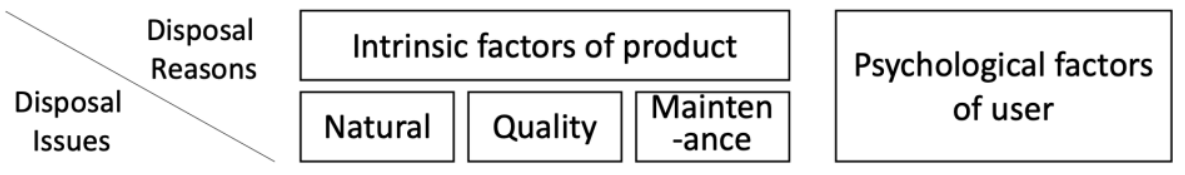

Extrinsic factors of product

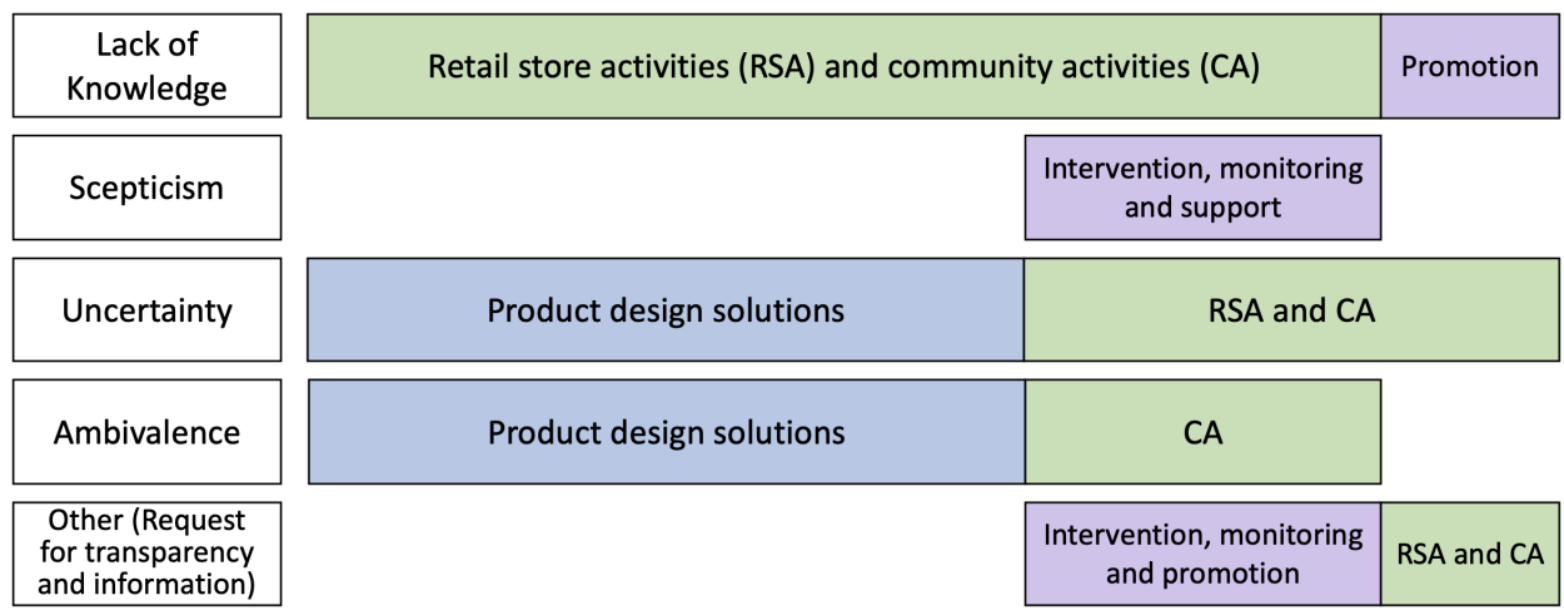

Product dimension $\square$ Service dimension $\square$ Policy dimension

Figure 5. Suggestion of design solution ideas for disposal reasons and issues. 


\subsection{Product Design Method}

Based on the results, several product design methods could be generated by reflecting on the issues of clothing disposal. A consideration will be made of how design methods could be adjusted to reflect the four main components of the survey. First, the design aimed at consumers' psychological factors could include ideas such as: easy-to-match items, popular replaceable elements, items of emotional significance, and the multi-purpose use of one item. Secondly, regarding the factors which are intrinsic to the product, the development of materials needs to balance factors such as the use of single component materials, high-quality material, durability (Karell \& Niinimä ki, 2020), and recyclable materials.

\subsection{Service Design Method}

Based on respondents regarding disposal practices, a proportion of consumers lack knowledge of clothing maintenance. Therefore, not only are proper maintenance instructions required, but customer service at the point of sale is expected, which includes the communication of the salesperson or the provision of activities such as tea ceremonies and lectures. Meanwhile, the information of disposal channels, recycling knowledge, and styling tips could also be shared through retail store activities and community activities in order to enhance the emotional significance of clothing to consumers and promote consumers' awareness. In addition, only a few retail shops in China currently provide a recycling box service which is expected to set up in more retail shops through government policy support. (See Figure 6).

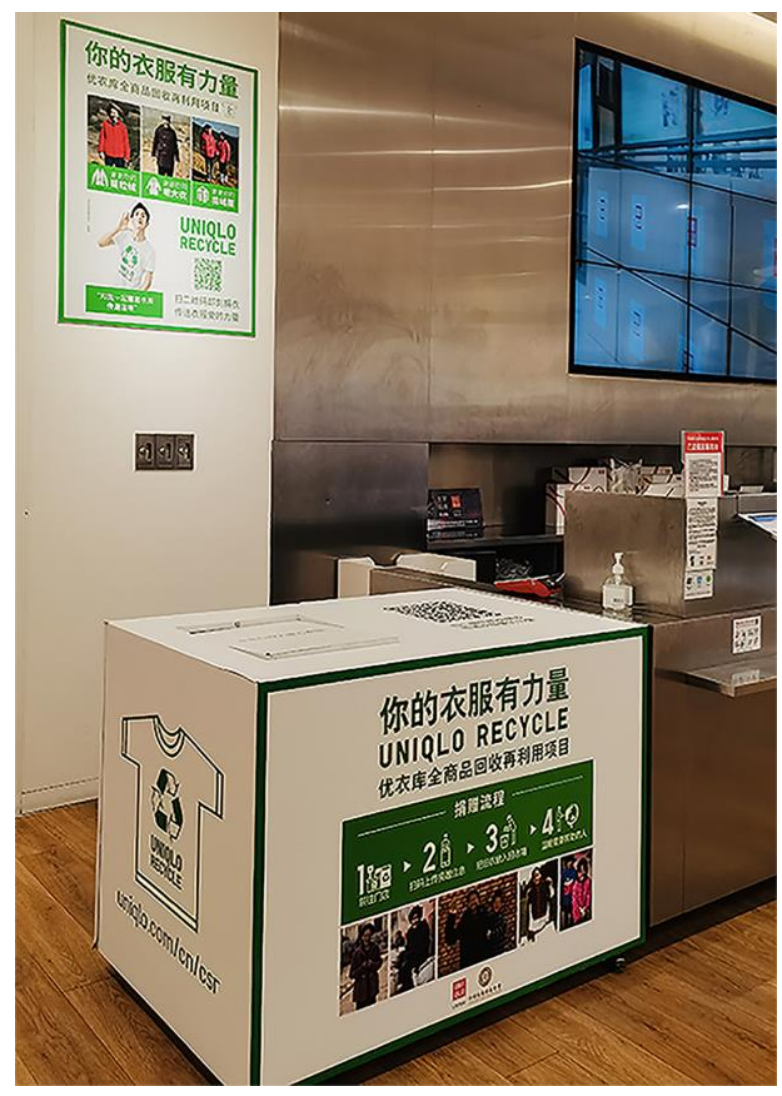

Figure 6. UNIQLO recycling box Source: author's own photograph.

\subsection{Disposal Policy Strategy}

The discrepancy between the requirements of clothing disposal organisations and the disposal behaviour of consumers indicates the lack of extensive publicity on this issue. The implementation of 
public policy is required for enhancing the transparency in disposal channels to disclose the destination information of items of donation, export and regeneration by the disposal organisations. Also, the channels of disposal organisations need to be monitored. An incentive mechanism for the manufacturers who adopt recyclable material and provide disposal services could be implemented. In addition, community recycling practices and relevant activities need to be strongly promoted through the cooperation of policymakers and community and disposal organisations.

\section{Conclusion}

\subsection{Implication}

The results of this study show that consumers are mainly driven by products' natural intrinsic factors and psychological factors to dispose of clothes, and there is a discrepancy between the requests of disposal organisations and the behaviour of consumers, as well as consumers' request for transparency in disposal channels. Thus, the sustainable design methods for recycling from the dimensions of product, service and policy strategy were proposed by reflecting on the issues of clothing disposal.

Although there has been academic research in the field of recycling, to a large extent, the relevant knowledge has not been extensively applied to the practices of design and disposal. Here, we propose the creation of a recycling method by reflecting on the issues of clothing disposal, and emphasising the intervention and monitoring by governments and the close collaboration among disposal organisations, communities, and policymakers to facilitate clothing recycling

\subsection{Limitation and Further Study}

This study has limitations as only conceptual sustainable design methods for recycling were proposed according to the disposal issues, and no specific practical scheme was described. Also, the limited sample size of interviews and survey cannot represent the opinions of all consumers. Moreover, as China has its own unique conditions, although the aim of the research was to propose a general concept which could be suitable for most countries. In addition, the surveyed disposal practices were not subdivided according to the features of clothing, such as brand, purchase price, and style.

For future study, more focus could be given to the following questions relating to design and disposal: 1) How can design practices and the specific disposal issues be combined? 2) How can recycling developments be kept in mind at the time of the design and how can designs be evaluated? 3) How can disposal channels be efficiently allocated according to the features of the clothing to achieve the target of recycling? 4) How can the government and community and disposal organisations engage together to promote the development of clothing disposal?

\section{References}

Barnes, L., Lea-Greenwood, G., Zarley Watson, M., \& Yan, R. N. (2013). An exploratory study of the decision processes of fast versus slow fashion consumers. Journal of Fashion Marketing and Management: An International Journal, 17(2), 141-159. https://doi.org/10.1108/JFMM-02-20110045

Bukhari, M. A., Carrasco-Gallego, R., \& Ponce-Cueto, E. (2018). Developing a national programme for textiles and clothing recovery. Waste Management and Research, 36(4), 321-331. https://doi.org/10.1177/0734242X18759190 
Claxton, S., \& Kent, A. (2020). The management of sustainable fashion design strategies: An analysis of the designer's role. Journal of Cleaner Production, 268, 122112.

https://doi.org/10.1016/j.jclepro.2020.122112

D'Adamo, I., \& Lupi, G. (2021). Sustainability and resilience after COVID-19: A circular premium in the fashion industry. Sustainability (Switzerland), 13(4), 1-5. https://doi.org/10.3390/su13041861

Degenstein, L. M., McQueen, R. H., \& Krogman, N. T. (2021). 'What goes where'? Characterizing Edmonton's municipal clothing waste stream and consumer clothing disposal. Journal of Cleaner Production, 296, 126516. https://doi.org/10.1016/j.jclepro.2021.126516

Diddi, S., Yan, R. N., Bloodhart, B., Bajtelsmit, V., \& McShane, K. (2019). Exploring young adult consumers' sustainable clothing consumption intention-behavior gap: A Behavioral Reasoning Theory perspective. Sustainable Production and Consumption, 18, 200-209. https://doi.org/10.1016/j.spc.2019.02.009

Gao Q; Huang, Z. (2012). Discussion on the Reverse Thinking in Packaging Design. PACKAGING ENGINEERING. Vol. 33 No.20 2012-10, 12-16.

https://doi.org/10.19554/j.cnki.1001-3563.2012.20.004

Goworek, H., Oxborrow, L., Claxton, S., McLaren, A., Cooper, T., \& Hill, H. (2018). Managing sustainability in the fashion business: Challenges in product development for clothing longevity in the UK. Journal of Business Research, 117(December 2017), 629-641. https://doi.org/10.1016/j.jbusres.2018.07.021

Hawley, J. M. (2009). Understanding and improving textile recycling: A systems perspective. Sustainable Textiles: Life Cycle and Environmental Impact, 179-199. https://doi.org/10.1533/9781845696948.1.179

Hu, Z.-H., Li, Q., Chen, X.-J., \& Wang, Y.-F. (2014). Sustainable rent-based closed-loop supply chain for fashion products. Sustainability (Switzerland), 6(10), 7063-7088. https://doi.org/10.3390/su6107063

Jacoby, J., Berning, C. K., \& Dietvorst, T. F. (1977). What about Disposition? Journal of Marketing, 41(2), 22. https://doi.org/10.2307/1250630

Joung, H. M., \& Park-Poaps, H. (2013). Factors motivating and influencing clothing disposal behaviours. International Journal of Consumer Studies, 37(1), 105-111. https://doi.org/10.1111/j.1470-6431.2011.01048.x

Kamis, A., Marcketti, S., Naam, M., Wahyuningsih, S. I., Sudana, I. M., Apriyani, D., \& Jamaluddin, R. (2019). Sustainable practice of clothes disposal: A review of critical literature. Journal of Advanced Research in Dynamical and Control Systems, 11(6 Special Issue), 1896-1900.

Karell, E., \& Niinimä ki, K. (2020). A mixed-method study of design practices and designers' roles in sustainable-minded clothing companies. Sustainability (Switzerland), 12(11). https://doi.org/10.3390/su12114680

Ki, C. W., Chong, S. M., \& Ha-Brookshire, J. E. (2020). How fashion can achieve sustainable development through a circular economy and stakeholder engagement: A systematic literature review. Corporate Social Responsibility and Environmental Management, 27(6), 2401-2424. https://doi.org/10.1002/csr.1970

Kozlowski, A., Searcy, C., \& Bardecki, M. (2018). The reDesign canvas: Fashion design as a tool for sustainability. Journal of Cleaner Production, 183, 194-207. https://doi.org/10.1016/j.jclepro.2018.02.014

Laitala, K. (2014). Consumers' clothing disposal behaviour - a synthesis of research results. International Journal of Consumer Studies, 38(5), 444-457. https://doi.org/10.1111/ijcs.12088

Myerson, J. (2016). Scaling Down: Why Designers Need to Reverse Their Thinking_Enhanced Reader.pdf (pp. 288-299). She Ji: The Journal of Design, Economics, and Innovation. https://doi.org/https://doi.org/10.1016/j.sheji.2017.06.001 
Shim, S. (1995). Environmentalism and Consumers' Clothing Disposal Patterns: An Exploratory Study. Clothing and Textiles Research Journal, 13(1), 38-48. https://doi.org/10.1177/0887302X9501300105

Wai Yee, L., Hassan, S. H., \& Ramayah, T. (2016). Sustainability and Philanthropic Awareness in Clothing Disposal Behavior Among Young Malaysian Consumers. SAGE Open, 6(1). https://doi.org/10.1177/2158244015625327

Weber, S., Lynes, J., \& Young, S. B. (2017). Fashion interest as a driver for consumer textile waste management: reuse, recycle or disposal. International Journal of Consumer Studies, 41(2), 207215. https://doi.org/10.1111/ijcs.12328

Young Lee, ji, Halter, H., Johnson, K. K. p., \& ju, H. (2013). Investigating fashion disposition with young consumers. Young Consumers, 14(1), 67-78. https://doi.org/10.1108/17473611311305494

Author Bios:

Author 1 Wenjun Guo is a Ph.D. candidate in School of Knowledge Science of Japan Advanced Institute of Science and Technology, and associate professor in Southampton International College of Dalian Polytechnic University. Her research interests include fashion and sustainability, fashion product research and development and creative textile design

Author 2 Eunyoung Kim is an associate professor in School of Knowledge Science of Japan Advanced Institute of Science and Technology. Her research interests include learning process design for creating innovations, social creativity and innovation, utilizing information technology for international development, business and management. 